\title{
PENGARUH LOAN TO DEPOSIT RATIO (LDR) TERHADAP NON PERFORMING LOAN (NPL) PADA BANK SYARIAH DAN BANK KONVENSIONAL DI INDONESIA
}

\author{
Oleh : \\ Budi S. Purnomo \\ (Dosen Program Studi Akuntansi Fakultas Pendidikan Ekonomi \& Bisnis UPI)
}

\begin{abstract}
Abstrak
Penelitian ini mengidentifikasikan masalah sebagai berikut : 1) Seberapa besar pengaruh Loan to Deposit Ratio (LDR) terhadap Non performing Loan (NPL) pada bank syariah, 2) Seberapa besar pengaruh Loan to Deposit Ratio (LDR) terhadap Non Performing Loan (NPL) pada bank konvensional. Metode penelitian yang digunakan adalah deskriptif verifikatif. Penelitian dilakukan dengan menganalisis tingkat LDR serta menguji pengaruh LDR terhadap NPL pada bank syariah dan bank konvensional. Pengujian analisis tingkat LDR menggunakan pengujian deskriptif dengan uji statistik satu pihak, kemudian pengujian pengaruh LDR terhadap LDR menggunakan pengujian asosiatif dengan uji statistik regresi linier sederhana dan korelasi product moment, dan koefisien determinasi $(\mathrm{Kd})$ digunakan untuk mengetahui besarnya pengaruh LDR terhadap NPL. Hasil penelitian menunjukan bahwa : 1) Berdasarkan hasil perhitungan statistik pada pengujian asosiatif, disimpulkan bahwa tidak terdapat pengaruh antara tingkat LDR terhadap NPL baik pada bank syariah maupun bank konvensional. Pada bank syariah, nilai korelasi antara LDR dengan NPL yaitu sebesar 0,6588. LDR memberikan pengaruh sebesar 43,40\%, sedangkan sisanya $56,6 \%$ dipengaruhi faktor lain. Pada bank konvensional, nilai korelasi antara tingkat LDR dengan NPL yaitu sebesar 0,6260 . LDR memberikan pengaruh sebesar $39,19 \%$, sedangkan sisanya $60,81 \%$ dipengaruhi faktor lain.
\end{abstract}

Kata kunci : Loan to Deposit ratio (LDR), Non Performing Loan (NPL)

\section{Latar Belakang}

Pada tahun 1998, tsunami krisis moneter di Indonesia berimbas pada sektor perbankan nasional, hingga sekitar 16 bank konvensional terkena likuidasi. Walau merasakan akibatnya, Bank Muamalat yang merupakan bank syariah mampu bertahan, bahkan termasuk diantara 72 bank yang dinyatakan sehat.

Seiring dengan makin bertambahnya jumlah bank syariah di Indonesia, jumlah dana yang dihimpun perbankan syariah pun terus bertambah, karena sistem bagi hasil yang ditawarkan perbankan syariah lebih stabil terhadap gejolak ekonomi makro. Kelebihan bank syariah yang tidak di pengaruhi oleh negative spread di tengah ketidak stabilan suku bunga bank konvensional, menyebabkan margin bagi hasil bank syariah memberikan keuntungan yang relatif lebih tinggi dibandingkan bunga yang ditawarkan oleh bank konvensional. Hal ini terjadi karena sistem bagi hasil diberikan berdasarkan nisbah (perbandingan bagi hasil) keuntungan yang disepakati saat nasabah membuka rekening.

Pembiayaan atau kredit merupakan salah satu instrument bank dalam memelihara likuiditas, solvabilitas dan rentabilitas. Salah satu instrument pengukuran analisis kinerja bank melalui rasio likuiditas tercermin pada tingkat Loan to Deposit Ratio (LDR) yang dicapai oleh bank terebut.

Pada tahun 2003 perbankan syariah di Indonesia telah mendanai pembiayaan sebesar Rp 5,53 Triliun dengan tingkat Loan to Deposit Ratio (LDR) atau disebut 
Financial to Deposit Ratio (FDR) pada bank syariah sebesar 96,6\%. Selama rentang waktu tahun 1997 sampai tahun 2003, tingkat FDR bank syariah jauh melebihi tingkat Loan to Deposit Ratio (LDR) bank konvensional di Indonesia, puncaknya adalah pada tahun 2000 dengan tingkat FDR bank syariah diatas 120\% sedangkan tingkat LDR bank konvensional kurang dari $40 \%$, prosentasi FDR bank syariah dan LDR bank konvensional dapat dilihat pada gambar berikut :

\section{Gambar 1.1}

Finance to Deposit Ratio (FDR) dan Loan to Deposit Ratio (LDR) pada Bank Syariah dan Konvensional di Indonesia

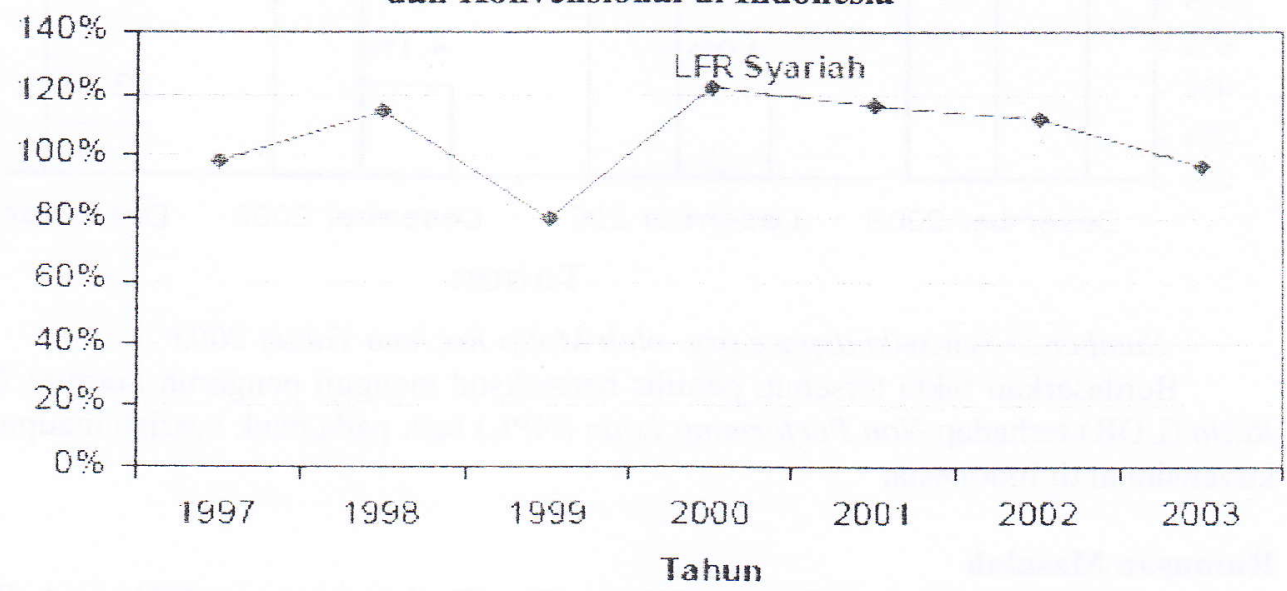

Sumber : www.wiki.dspace.org oleh Malia Rochma Tahun 2003

Untuk memelihara tingkat kesehatan, para pengelola bank diharuskan memantau kualitas aktiva produktif. Ukuran utamanya adalah ketepatan pembayaran kembali pokok dan bunga serta kemampuan debitur ditinjau dari usaha maupun nilai agunan kredit yang bersangkutan. Berdasarkan Peraturan Bank Indoesia No. 8/2/PBl/2006 tentang perubahan atas PBI No 7/2/PBI/2005 Perihal Penilaian Kualitas Aktiva Bank Umum dan pembentukan cadangan, ditetapkan 5 (lima) golongan kolektibilitas kredit, yaitu : Lancar (pass), Perhatian Khusus (Special Mention), Kurang Lancar (Sub Standard), Diragukan (doubtful), dan Macet (loss).

Mekanisme penilaian tingkat kesehatan bank saat ini mengacu pada Peraturan Bank Indonesia No.6/10/PBI/2004 perihal Sistem Penilaian Kesehatan Bank Umum, salah satu faktor penilaiannya adalah menggunakan kualitas aset dengan komponen Kinerja Penanganan Aktiva Produktif Bermasalah yaitu menggunakan rasio Non Performing Loan (NPL).

Tingkat kehati-hatian (prudential banking) perbankan syariah tercermin dari rasio Non Performing Loan (NPL) terhadap total loans sebesar 2,3\% pada Desember 2003, stabil di bawah 5\% sejak tahun 2000. Sementara itu NPL bank konvensional selama dalam rentang waktu tahun 2000 sampai tahun 2003 masih diatas $8 \%$. Berikut merupakan bagan perbandingan NPL syariah dengan NPL konvensional di Indonesia : 


\section{Gambar1.2}

Non Performing Loan (NPL) pada Bank Syariah dan Konvensional di Indonesia

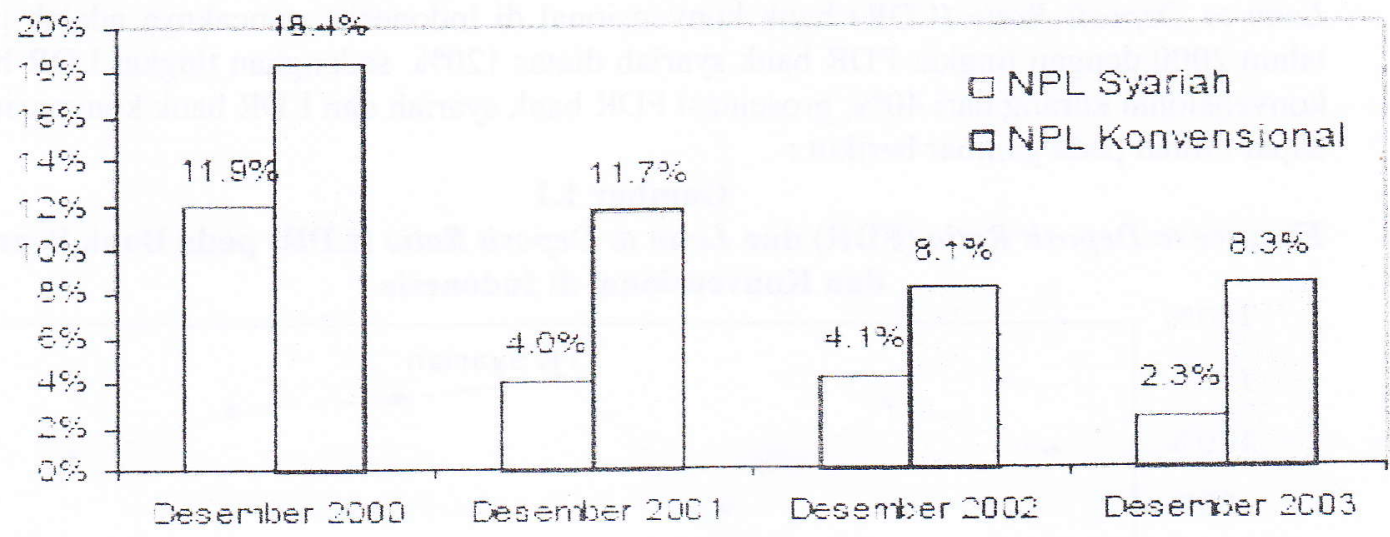

\section{Tahum}

Sumber : www.wikidspace. org oleh Malia Rochma Tahun 2003

Berdasarkan fakta tersebut, penulis bermaksud menguji pengaruh Loan to Deposit Ratio (LDR) terhadap Non Performing Loan (NPL) baik pada bank syariah maupun bank kovensional di Indonesia.

\section{Rumusan Masalah}

1. Bagaimana Loan Deposit Ratio (LDR) dan Non Performing Loan (NPL) pada Bank Syariah dan Bank Konvensional di Indonesia?

2. Bagaimana Pengaruh Loan Deposit Ratio (LDR) terhadap Non Performing Loan (NPL) pada Bank Syariah dan Bank Konvensional di Indonesia?

\section{Kerangka Pemikiran}

Likuiditas bank merupakan salah satu unsur untuk melakukan penilaian tingkat kesehatan bank, penilaiannya mengacu pada peraturan Bank Indonesia No.6/10/PBI/2004 perihal sistem penilaian Tingkat Kesehatan Bank Umum dan Surat Edaran No.6/23/DPNP Jakarta, 31 Mei 2004 perihal Sistem Penilaian Tingkat Kesehatan Bank Umum, yang salah satunya menggunakan Loan to Depsit Ratio (LDR) untuk bank konvensional atau Financial to Deposit Ratio (FDR) pada bank syariah, dalam penelitian ini menggunakan istilah Loan to Deposit Ratio (LDR). LDR menurut Lukman $(2005,116)$ dapat diartikan sebagai rasio antara seluruh jumlah kredit yang diberikan bank dengan dana yang diterima oleh bank, dan dapat dihitung dengan rumus sebagai berikut:

\section{Loan to Depsit Ratio $\quad=\frac{\text { Kredit yang diberikan }}{\text { Dana pihak ketiga }}$}

a. Kredit merupakan total kredit yang diberikan kepada pihak ketiga (tidak termasuk kredit pada pihak lain),

b. Dana pihak ketiga mencakup giro, tabungan dan deposito (tidak termasuk antar bank)

Dalam tata cara penilaian tingkat kesehatan bank untuk Loan to Deposit Ratio (LDR) menurut PBI No. 6/10/PBI/2004 tentang Sistem Penilaian Tingkat Kesehatan Bank Umum, Bank Indonesia menetapkan ketentuan sebagai berikut : 
Tabel 2.1 Kriteria Penetapan Peringkat Komponen Likuiditas

\begin{tabular}{|c|c|}
\hline Komponen & Loan to Deposit Ratio (LDR) \\
\hline Peringkat 1 & $50 \% \therefore$ rasio $\because 75 \%$ \\
\hline Peringkat 2 & $75 \% \therefore$ rasio $\therefore 85 \%$ \\
\hline Peringkat 3 & $85 \%$ rasio $\because 100 \%$ atau rasio $\because 50 \%$ \\
\hline Peringkat 4 & $100 \% \therefore$ rasio $\because 120 \%$ \\
\hline Peringkat 5 & Rasio $\because 120 \%$ \\
\hline
\end{tabular}

Dari tabel 2.1 tersebut, sebagian praktisi perbankan menyepakati bahwa batas aman dari Loan to Deposit Ratio (LDR) adalah sekitar $80 \%$ dengan batas toleransi berkisar $85 \%$ dan $100 \%$.

Kredit bermasalah atau disebut Non Performing Finance (NPF) pada bank syariah dan Non Performing Loan (NPL) pada bank konvensional, pada umumnya merupakan kredit yang pembayaran angsuran pokok dan atau bunganya telah lewat 90 hari atau lebih setelah jatuh tempo atau kredit yang pembayarannya secara tepat waktu sangat diragukan (PSAK No.31 tahun 2004). Menurut Lukman $(2005,82)$ NPL terutama disebabkan oleh kegagalan pihak debitur memenuhi kewajibannya untuk membayar angsuran (cicilan) pokok pembiayaan/kredit beserta bunganya untuk bank konvensional yang telah disepakati oleh kedua belah pihak dalam perjanjian pembiataan/kredit.

Berdasarkan Surat Edaran No.6/23/DPDN tanggal 31 Mei 2004 tentang perhitungan rasio keuangan bank, NPL dihitung sebagai berikut :

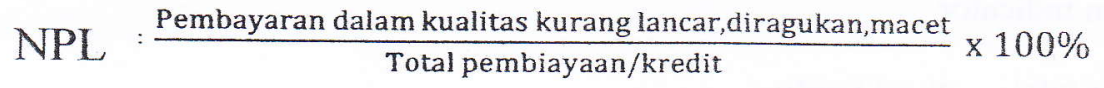

Pembiayaan/kredit lancar yang diberikan bank dapat berubah menjadi pembiayaan/kredit bermasalah (Non Performing Loan) dengan kategori kurang lancar, diragukan dan macet. Meskipun tidak dapat menghindari sepenuhnya resiko dari pembiayaan/kredit, namun diusahakan agar jumlah Non Performing Loan pada bank umum berada dalam batas wajar, yaitu tidak lebih dari $5 \%$, atau berkisar $5 \%-8 \%$ menurut penilaian tingkat kesehatan bank yang mengacu pada PBI No. 6/10/PBI/2004 tentang Sistem Penilaian Tingkat Kesehatan Bank Umum.

Kualitas pembiayaan/kredit salah satunya dipengaruhi oleh seberapa besar Loan to deposit ratio (LDR) yang dicapai bank. Kualitas pembiayaan/kredit yang baik, tidak akan melampaui batas Loan to deposit ratio (LDR) yang sudah di tentukan oleh Bank Indonesia, hal ini sebagaimana diungkapkan oleh Taswan $(2006,182)$. Karena semakin besarnya penyaluran dana dalam bentuk pembiayaan/kredit relatif dibandingkan dengan simpanan masyarakat pada suatu bank membawa konsekuensi semakin besarnya resiko yang ditanggung oleh bank yang bersangkutan (Sri Y.Susilo, 1999,32). Berdasarkan hal tersebut, dapat dikatakan bahwa terdapat hubungan saling mempengaruhi antara Non Performing Loan (NPL) dengan tingkat Likuiditas bank yang tercermin pada Loan to Deposit Ratio (LDR).

Mengacu pada pemikiran di atas, maka penelitian ini akan menguji apakah Loan to Deposit ratio akan berpengaruh terhadap Non Performing Loan (NPL), baik pada bank syariah maupun bank konvensional.

$\mathrm{H}_{\mathrm{al}}$ : Loan to Deposit (LDR) berpengaruh terhadap Non Performing Loan (NPL) pada bank syariah;

$\mathrm{H}_{\mathrm{a} 2}$ : Loan to Deposit (LDR) berpengaruh terhadap Non Performing Loan (NPL) pada bank konvensional; 


\section{Metode Penelitian}

Populasi dalam penelitian ini adalah laporan keuangan bank syariah di Indonesia dengan jumlah 3 bank, dan laporan keuangan bank konvensional di Indonesia dengan jumlah 131 bank, termasuk didalamnya 9 bank umum konvensional yang memiliki unit usaha syariah pada tahun 2007. Pemilihan sampel dilakukan dengan metode purposive sampling dengan criteria sebagai berikut:

1) Bank umum syariah dan bank umum konvensional dengan total aset tertinggi di Indonesia,

2) Bank umum yang tidak memiliki unit usaha syariah,

3) Laporan keuangan yang digunakan pada penelitian ini adalah laporan keuangan pada tahun $2003 \mathrm{~s} / \mathrm{d} 2006$ yang telah audit dan dipublikasikan.

Berdasarkan kriteria tersebut, jumlah sampel yang digunakan dalam penelitian ini terdapat pada table 3.1. di bawah ini :

Tabel 3.1. Bank Umum Syariah dan Bank Umum Konvensional Merurut Total Aktiva pada Tahun 2003 di Indonesia

\begin{tabular}{|c|l|l|}
\hline No & Bank Umum Konvensional & Bank Umum Syariah \\
\hline 1. & Bank Mandiri & Bank Muamalat \\
\hline 2. & Bank Negara Indonesia & Bank Syariah Mandiri \\
\hline 3. & Bank Central Asia & \\
\hline
\end{tabular}
Sumber: Biro Riset Info Bank, Maret 2004

a. Loan to Deposit Ratio (LDR) adalah rasio antara seluruh jumlah kredit yang diberikan bank dengan dana yang diterima oleh bank. (Lukman,2005,116), dengan indicator

$$
\mathrm{LDR}=\frac{\text { Total kredit }}{\text { Dana Pihak ketiga }}
$$

b. Non performing Loan (NPL) merupakan kredit yang pembayaran angsuran pokok dan atau bunganya telah lewat 90 hari atau lebih setelah jatuh tempo atau kredit yang pembayarannya secara tepat waktu sangat diragukan (PSAK No.31 tahun 2004), dengan indicator:

$$
\mathrm{NPL}=\frac{\text { Kredit bermasalah }}{\text { Total kredit }}
$$

\subsection{Model Analisis dan Pengujian Hipotesis}

1) Analisis Korelasi Sederhana

Perhitungan koefisien korelasi

dilakukan dengan rumus sebagai berikut :

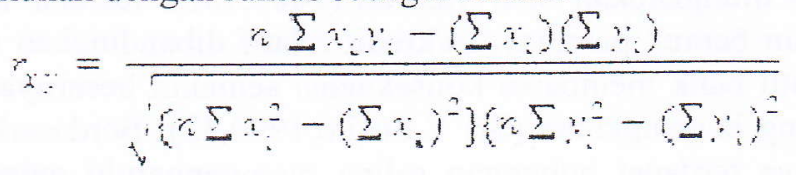

Dimana :

$r_{x y}=$ korelasi antara variabel $\mathrm{X}$ dan $\mathrm{Y}$

$\sum X_{i} \quad=$ jumlah variabel $X$

$\sum Y_{i} \quad=$ jumlah variabel $Y$

2) Koefisien Determinasi

Perhitungan koefisien determinasi dilakukan dengan rumus berikut :

$$
K D=r^{2} \times 100 \%
$$


Dimana :

$\mathrm{KD}=$ koefisien determinasi

$r \quad=$ koefisien korelasi

3) Analisis Regresi Linier Sederhana

Analisis ini menggunakan rumus sebagai berikut :

$\mathrm{Y}=\mathrm{a}+\mathrm{bX}$

Dengan :

$\mathrm{a}=\frac{\left(\sum X_{i}^{2}\right)\left(\sum Y_{i}\right)-\left(\sum X_{i}\right)\left(\sum X_{i} Y_{i}\right)}{n \sum X_{i}^{2}-\left(\sum X_{i}\right)^{2}}$

$\mathrm{b}=\frac{n \sum X_{i} Y_{i}-\left(\sum X_{i}\right)\left(\sum Y_{i}\right)}{n \sum X_{i}^{2}-\left(\sum X_{i}\right)^{2}}$

dimana :

$Y=$ subjek dalam variabel dependen yang diprediksikan

$\mathrm{a}=$ harga $\mathrm{Y}$ bila $\mathrm{X}=0$

$\mathrm{b}=$ angka arah atau koefisien regresi

$\mathrm{X}=$ subjek pada variabel independen yang mempunyai nilai tertentu

4) Pengujian Hipotesis Asosiatif

Pengujian hipotesis dalam penelitian ini, menggunakan uji t satu pihak, dengan membandingkan $t_{\text {tabel }}$ dengan $t_{\text {hitung }}$ yang dirumuskan sebagai berikut :

Dimana :

$$
t=\frac{r_{x y \sqrt{n-2}}}{\sqrt{1-r^{2}}}
$$

$\mathrm{n} \quad=$ jumlah responden

$\mathrm{r}_{\mathrm{xy}} \quad=$ koefisien korelasi pearson

t $=$ nilai signifikansi

\section{Hasil Penelitian}

\section{Uji pengaruh pada bank Syariah}

1. Analisis korelasi

Hasil persamaan koefisien korelasi product moment untuk bank syariah adalah sebagai berikut :

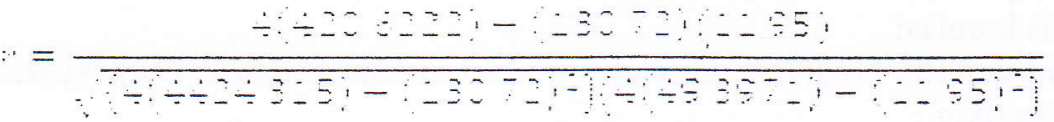

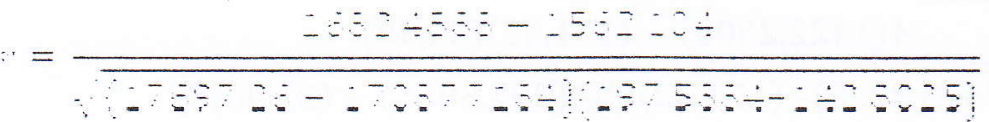

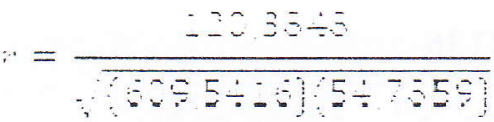

$$
\begin{aligned}
& \cdots=\frac{120.3848}{\sqrt{3339+2851}}
\end{aligned}
$$

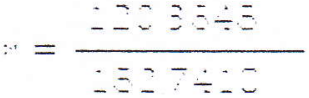

$$
\begin{aligned}
& \because=2: 558
\end{aligned}
$$

Nilai koefisien korelasi sebesar 0,6588 berarti tingkat hubungan antara Loan to Deposit Ratio dengan Non Performing Loan bank syariah adalah tinggi kuat. 
2. Koefisien deternimasi

$$
\begin{aligned}
& \mathrm{kd}=\mathrm{r}^{2} \times 1000 \\
& \mathrm{H}=0,650 \mathrm{x} 100 \\
& \mathrm{a}=\div 3 \div 2
\end{aligned}
$$

Nilai koefisien determinasi bank syariah sebesar $43,40 \%$, ini berarti bahwa $43,40 \%$ Non Performing Loan disebabkan oleh Loan to Deposit Ratio.

3. Analisis regresi linier sederhana

Hasil perhitungan regresi linier sederhana adalah antara LDR dengan NPL pada bank syariah adalah :

$$
\begin{aligned}
& a=\frac{(4+24,315)(11,95)-(130,72)(420,6222)}{4(4424,315)-(130,72)^{2}}
\end{aligned}
$$

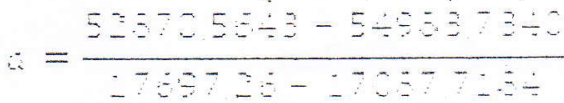

$$
\begin{aligned}
& \therefore=\frac{-203-50}{30506} \\
& \therefore=-3- \\
& b=\frac{n \sum X_{i} Y_{i}-\left(\sum X_{i}\right)\left(\sum Y_{i}\right)}{n \sum X_{i}^{2}-\left(\sum X_{i}\right)^{2}} \\
& b=\frac{4(420.6222)-(13072)(1195)}{4(4424315)-(13072)^{2}} \\
& b=\frac{1682,4888-1562,104}{17697,26-17087,7184} \\
& \therefore=\frac{-105 \div 5}{305 \div 5} \\
& b=0,20
\end{aligned}
$$

Dari perhitungan diatas maka persamaan regresinya adalah :

$$
Y=-3,47+0,20 \%
$$

\section{Uji pengaruh pada bank Konvensional}

1. Analisis korelasi

Hasil persamaan koefisien korelasi product moment untuk bank syariah adalah sebagai berikut :

$$
\begin{aligned}
& r=\frac{4(1422,2503)-(171,32)(31,98)}{\sqrt{\left\{4(7473,3738)-(171,32)^{2}\right\}\left\{4(307,5866)-(31,98)^{2}\right\}}} \\
& r=\frac{5689,0012-5478,8136}{\sqrt{(29893,4952-29350,5424)(1230,3464-1022,7204)}} \\
& r=\frac{5689,0012-5478,8136}{\sqrt{542,9528,207,626}} \\
& r=\frac{210,1876}{335,7546} \\
& r=0,6260
\end{aligned}
$$


Nilai koefisien korelasi sebesar 0,6260 berarti tingkat hubungan antara Loan to Deposit Ratio dengan Non Performing Loan bank konvensional adalah tinggi kuat.

2. Koefisien deternimasi

$k d=\mathrm{r}^{2} \mathrm{x} 100 \%$

$k d=0,6260^{2} x 100 \%$

$k d=39,19 \%$

Nilai koefisien determinasi bank syariah sebesar 39,19\%, ini berarti bahwa 39,19\% Non Performing Loan disebabkan oleh Loan to Deposit Ratio.

3. Analisis regresi linier sederhana

Hasil perhitungan regresi linier sederhana adalah antara LDR dengan NPL pada bank syariah adalah :

$$
\begin{aligned}
& a=\frac{(7473,3738)(31,98)-(171,32)(1422,2503)}{4.7473,3738-(171,32)^{2}} \\
& a=\frac{238998,4941-243659,9214}{29893,4952-29350,5424} \\
& a=\frac{-4661,4273}{542,9528} \\
& a=-8,59 \\
& b=\frac{4.1422,2503-(171,32)(31,98)}{4.7473,3738-(171,32)^{2}} \\
& b=\frac{5689,0012-5478,8136}{29893,4952-29350,5424} \\
& b=\frac{210,1876}{542,9528} \\
& b=0,39
\end{aligned}
$$

Dari perhitungan diatas maka persamaan regresinya adalah :

$$
Y=-8,59+0,39 x \text {. }
$$

\section{Simpulan}

Berdasarkan hasil perhitungan statistik, disimpulkan bahwa tidak terdapat pengaruh antara tingkat Loan to Deposit Ratio terhadap Non Performing Loan baik pada bank syariah maupun bank konvensional.

\section{Saran}

Penelitian selanjutnya dapat memperluas sampel dan periode laporan keuangannya, serta menambah variable penelitian lain seperti Batas Maksimum Pemberian Kredit atau Pembiayaan (BMPK/BMPP), leanding Rate dan analisis pemberian pembiayaan atau kredit yang dapat mempengaruhi Non Performing Loan selain Loan to Deposit Ratio. 


\section{Daftar Pustaka}

Bank Indonesia. 2004. Peraturan Bank Indonesia No.6/10/PBI/2004. Jakarta: www.bi.go.id.

Bank Indonesia. 2006. Peraturan Bank Indonesia No.7/2/PBI/2006. Jakarta: www.bi.go.id.

Bank Indonesia. 2006. Peraturan Bank Indonesia No.8/2/PBI/2006. Jakarta: www.bi.go.id.

Bank Indonesia. 2007. Peraturan Bank Indonesia No.9/1/PBI/2007. Jakarta: www.bi.go.id.

Bank Indonesia. 2004. Surat Edaran Bank Indonesia No.6/23/DPNP/2004. Jakarta: www.bi.go.id

Lukman Dendawijaya,. 2005. Manajemen Perbankan. Jakarta : Ghalia.

Muhammad Djuman Hara,. 2006. Hukum Perbankan di Indonesia. Bandung : PT. Citra Aditya Bakti.

M.lqbal Hasan. 2002. Pokok-pokok Metodologi Penelitian dan Aplikasinya. Jakarta : Ghalia.

Malayu Hasibuan. 2004. Dasar-dasar Perbankan. Jakarta : Aksara.

IAI. 2007, Standar Akuntansi Keuangan. Jakarta: Salemba Empat.

Kasmir, 2006. Manajemen Perbankan. Jakarta: Grafindo Persada.

PT. Bank Central Asia Tbk. 2006. Laporan Keuangan Tahun 2003-2006. Jakarta: www.klikbca.com.

PT. Bank Mandiri (Persero) Tbk. 2006. Laporan Keuangan Tahun 2003-2006. Jakarta : www.bankmandiri.co.id.

PT. Bank Muamalat Indonesia Tbk. 2006. Laporan Keuangan Tahun 2003-2006. Jakarta: www.muamalatbank.com.

PT. Bank Syariah Mandiri. 2006. Laporan Keuangan Tahun 2003-2006. Jakarta : www.syariahmandiri.co.id.

Sugiyono. 2006. Statistik Untuk Penelitian. Bandung : Alfabeta.

Muhammad Syafi'I Antonio. 2001. Bank Syariah Dari Teori ke Praktik. Jakarta : Gema Insani.

Taswan. 2006. Manajemen Perbankan : Konsep, Teknik dan Aplikasi. Yogyakarta : UUP STIM YPKN.

Sunarto Zulkifli. 2003. Panduan Praktis Transaksi Perbankan Syariah. Jakarta : Zukrul Hakim. 